\title{
CORRESPONDENCE
}

\section{Possible Devonian Uplift on the Swansea Valley Fault, Wales}

SIR - The Swansea Valley Fault system is an important structural feature in South Wales (Owen, 1954; Weaver, 1975), with a known Hercynian phase of movement believed to be controlled by sub-Carboniferous basement structures (Weaver, 1975). This note suggests that localized, preHercynian movements may have occurred along the line of the Swansea Valley, during Devonian times.

The Lower Old Red Sandstone of the Swansea Valley area is poorly known and, until recently, no detailed studies had been made of these rocks. The sediments normally consist of medium- to fine-grained red sandstones and siltstones. In the higher parts of the Lower Old Red Sandstone to the west of the Swansea Valley, unusually coarse, pebbly sediments have been locally found, of a type not normally seen in these beds.

The Brownstones form the highest Lower Old Red Sandstone in South Wales (Allen, 1974a), and are magnificently exposed on scarp faces around the $\mathrm{N}$ crop of the South Wales Coalfield. Typically, the sandstones are medium-fine grained and parallel laminated, with primary current lineation. They occur in 30-100 cm thick beds which persist laterally for $300-400 \mathrm{~m}$, alternating with equally persistent siltstones. They resemble semi-arid sheetflood deposits (Rahn, 1967; Williams, 1970), and may have formed on extensive sandy alluvial cones (cf. Gole \& Chitale, 1966). Regional palaeocurrents are from the N and NW (Allen, 1974a). (Data measured in the Swansea Valley and Brecon Beacons shows Vector Mean $165^{\circ}$, Variance $52^{\circ}$, number of readings 28 , measured from cross sets with thicknesses in the range $15-40 \mathrm{~cm}$ ). In marked contrast to this regionally widespread facies are localized, coarsegrained deposits found some $100 \mathrm{~m}$ from the top of the Brownstones around Llyn-y-Fan-Fawr (U.K. grid reference SN 834216), some $4 \mathrm{~km} \mathrm{~W}$ of the Swansea Valley. Here occurs an interval of coarse, cross-bedded pebbly sandstones and conglomerates with highly angular exotic clasts. Pebble types include acid volcanics, lithic arenites and vein quartz. Siltstones are rare here. Soft sediment deformations, suggestive of vertical water escape, are notably more abundant than elsewhere in the Brownstones. Palaeocurrents in this coarse facies are from the $\mathrm{E}$ (Vector mean $254^{\circ}$ Variance $58^{\circ}$, number of readings 33 , measured from cross sets $30-60 \mathrm{~cm}$ thick). The sediments are reminiscent of braided stream sediments (cf. Ore, 1964; Rust, 1972).

The coarse sediments can be traced for only a few $\mathrm{km}$, and are not seen to the $\mathrm{E}$ of the Swansea Valley. The coarse interval passes to finer, non-pebbly sandstones with southerly directed palaeocurrents, typical of the Brownstones throughout the South Wales outcrop. This junction is marked by a $2 \mathrm{~m}$ thick siltstone containing $8-10 \mathrm{~cm}$ wide calcrete glaebules - a feature seen rarely in the Brownstones, and suggestive of a marked pause in sedimentation (Leeder, 1975, 1976).

The palaeocurrents seen in the coarse interval suggest a localized, relatively short-lived change in the drainage pattern in the area $\mathrm{W}$ of the Swansea Valley. Coarse, highly angular tuff pebbles point to only short transport distances, as rocks of this type round quickly under transportation (Pearce, 1971). The palaeocurrents suggest uplift to the $E$. This may have been along a portion of the Swansea Valley, for no coarse clastics are found $\mathrm{E}$ of that line. Deposition seems to have been restricted to the Llyn-y-Fan-Fawr area, and only prevailed for a relatively short period before the southerly directed drainage system was restored.

Hercynian movements on the Swansea Valley are possibly controlled by strike-slip basement movements (Weaver, 1975). Localized, short-lived uplifts are characteristic of this type of fault belt, caused by differential movement of fault branches, and often associated with seismic activity (Reading, 1975; Crowell, 1974). Seismic events associated with fault movements may explain the abundant soft sediment deformations found in the coarse interval.

The coarse-grained sediments of Llyn-y-Fan-Fawr may, therefore, represent deposits produced by early movement on part of the Swansea Valley Fault System which, for a relatively short period of time, locally altered the basin drainage to a westerly directed flow. The source of the exotic material is problematic. The clast assemblage points to a source of high-level crustal rocks, consisting of volcanics and sediments. Such sources may be broadly matched with lower Palaezoic rocks of south and central Wales (Allen, 1974a,b). Whether such material lies locally at shallow depths along the Swansea Valley fault system is at present unknown. 


\section{References}

Allen, J. R. L. 1974(a). The Devonian rocks of Wales and the Welsh Borderland. In The Upper Palaeozoic and Post-Palaeozoic rocks of Wales (ed. T. R. Owen), pp. 47-84. Cardiff: University of Wales Press.

Allen, J. R. L. 1974(b). Source rocks of the Lower Old Red Sandstone: Exotic pebbles from the Brownstones, Ross-on-Wye, Hereford and Worcester. Proc. Geol. Ass. 85, 493-510.

Crowell, J.C. 1974. Origin of late Cenozoic basins in Southern California. In Tectonics and Sedimentation (ed. W. R. Dickinson). Soc. Econ. Palaeont. Miner. Spec. Publ. 22, 194-204.

Gole, C. V. \& Chitale, S. V. 1966. Inland delta building activity of the Kosi River. Proc. Am. Soc. Civil Engrs. Jour. Hydraulics Div. HY 2, 92, 111-22.

Leeder, M. R. 1975. Pedogenic carbonates and flood sediment accretion rates: a quantitative model for alluvial arid zone lithofacies. Geol. Mag. 112, 257-70.

Leeder, M. R. 1976. Palaeogeographic significance of pedogenic carbonates in the topmost Upper Red Sandstone of the Scottish Border Basin. Geol. J. 11, 21-8.

Ore, H. T. 1964. Some criteria for recognition of braided stream deposits. Univ. Wyoming Contr. Geol. 3, 1-14.

Owen, T. R. 1954. The structure of the Neath disturbance between Bryniau Glesion and Glynneath, South Wales. $Q . J l$ geol. Soc. Lond. 109, 333-65.

Pearce, T. H. 1971. Short distance fluvial rounding of volcanic detritus. J. sedim. Petrol. 41, 1069-72.

Rahn, P. H. 1967. Sheetfloods, streamfloods and the formation of pediments. Ann. Amer. Ass. Geogr. 57, 593-604.

Reading, H. G. 1975. Strike-slip fault systems; an ancient example from the Cantabrians. Proc. 11 th Int. Sedim. Congress, Nice.

Rust, B. R. 1972. Structure and process in a braided river. Sedimentology 18, 221-45.

Weaver, J. D. 1975. The structure of the Swansea Valley disturbance between Clydach and Hay-on-Wye, South Wales. Geol. J. 10, 75-86.

Williams, G. E. 1970. Piedmont sedimentation and late Quaternary chronology in the Biskra region of the Northern Sahara. Z. Geomorph. Suppl. 10, 40-63.

Dept of Environmental Sciences

I. P. TUNBRIDGE

Plymouth Polytechnic

Drake Circus

Plymouth PL4 8AA

Devon.

11 th December 1979 